\title{
Brevibacterium picturae sp. nov., isolated from a damaged mural painting at the Saint-Catherine chapel (Castle Herberstein, Austria)
}

\author{
Jeroen Heyrman, ${ }^{1}$ Jens Verbeeren, ${ }^{1}$ Peter Schumann, ${ }^{3}$ Joke Devos, ${ }^{1}$ \\ Jean Swings ${ }^{1,2}$ and Paul De Vos ${ }^{1}$ \\ 1,2Vakgroep BFM WE10V, Laboratorium voor Microbiologie, Universiteit Gent ${ }^{1}$, and BCCM/LMG \\ Bacteria Collection², K. L. Ledeganckstraat 35, B-9000 Gent, Belgium
}

Jeroen Heyrman Jeroen.Heyrman@UGent.be
${ }^{3} \mathrm{DSMZ}$ - Deutsche Sammlung von Mikroorganismen und Zellkulturen, Mascheroder Weg 1b, D-38124 Braunschweig, Germany

\begin{abstract}
Three strains showing highly similar $(\mathrm{GTG})_{5}$-PCR patterns were isolated from a heavily damaged mural painting at the Saint-Catherine chapel (Castle Herberstein, Austria). On the basis of 16S rRNA gene sequence similarity, the strains were attributed to Brevibacterium, with Brevibacterium casei (96.7\%), Brevibacterium iodinum (96.7\%) and Brevibacterium linens $(96.6 \%)$ as the closest related species. Chemotaxonomic data [peptidoglycan contains meso-diaminopimelic acid; mycolic acids absent; $\mathrm{MK}-8\left(\mathrm{H}_{2}\right)$ as the major menaquinone; polar lipids phosphatidylglycerol and diphosphatidylglycerol present; anteiso- $\mathrm{C}_{15: 0}$ and anteiso- $\mathrm{C}_{17: 0}$ as major fatty acids] supported the affiliation of the strains to the genus Brevibacterium.

Additional physiological and biochemical tests confirmed the taxonomic position of the strains and allowed phenotypic differentiation from Brevibacterium species with validly published names. The isolates from the mural painting, therefore, represent a novel species, for which the name Brevibacterium picturae sp. nov. is proposed, with LMG $22061^{\top}\left(=\mathrm{DSM} 16132^{\top}\right)$ as the type strain.
\end{abstract}

After the initial description of the genus Brevibacterium by Breed (1953), the genus served as a depository for various Gram-positive rods later shown in chemotaxonomic studies to belong to different coryneform genera (Collins, 1992). The description of the genus was consequently emended to embrace only those species that correspond to the type species, Brevibacterium linens, in genus-specific characteristics (Collins et al., 1980). In addition to Brevibacterium linens, eight other species of the genus are currently recognized: Brevibacterium iodinum (Collins et al., 1980), Brevibacterium casei (Collins et al., 1983), Brevibacterium epidermidis (Collins et al., 1983), Brevibacterium mcbrellneri (McBride et al., 1993), Brevibacterium otitidis (Pascual et al., 1996), Brevibacterium avium (Pascual \& Collins, 1999), Brevibacterium paucivorans (Wauters et al., 2001) and Brevibacterium lutescens (Wauters et al., 2003). Euzeby \& Tindall (2004) have requested an opinion of the Judicial Commission to change the name of Brevibacterium lutescens

Published online ahead of print on 27 February 2004 as DOI 10.1099/ ijs.0.63144-0.

The GenBank/EMBL/DDBJ accession numbers for the 16S rRNA gene sequences of strains LMG $22061^{\top}$ (=DSM 16132 $)$, LMG 22062 and LMG 22063 are AJ620364-AJ620366.

Supplementary data on fatty acid profiles are available in IJSEM Online. to Brevibacterium luteolum. Brevibacterium liquefaciens was shown to be a synonym of Arthrobacter nicotianae (Stackebrandt et al., 1983), yet this synonymy has only recently been validated (Gelsomino et al., 2004). Three other species, Brevibacterium halotolerans, Brevibacterium frigoritolerans and Brevibacterium stationis, have not been subjected to genetic studies and their taxonomic positions therefore remain uncertain (Jones \& Keddie, 1986).

During the study of bacteria isolated from damaged mural paintings originating from three European sites, three strains were recovered from a sample of a paint layer, showing black discoloration, located in the chancel vault of the Saint-Catherine chapel of Castle Herberstein in Austria. Strain LMG $22061^{\mathrm{T}}$ was first isolated by using R2A agar (Difco) supplemented with $1 \%(\mathrm{w} / \mathrm{v}) \mathrm{NaCl}$; strains $\mathrm{LMG}$ 22062 and LMG 22063 were isolated from tryptone soy agar (TSA) supplemented with $10 \%$ (w/v) NaCl. Subcultivation was done on TSA plus $10 \%(\mathrm{w} / \mathrm{v}) \mathrm{NaCl}$ and marine agar (Difco). Strains were also able to grow on TSA and nutrient agar (NA; Oxoid). Salt tolerance and $\mathrm{pH}$ range were tested. For salt-tolerance testing, tryptone soy broth (TSB) to which $0,5,10$ and $15 \%(\mathrm{w} / \mathrm{v})$ salt had been added was used. To assess the $\mathrm{pH}$ range, the $\mathrm{pH}$ was adjusted from $\mathrm{pH} 4 \cdot 0$ to $\mathrm{pH} 10 \cdot 0$ at 0.5 unit intervals. Results were monitored after $72 \mathrm{~h}$ incubation at $28^{\circ} \mathrm{C}$ and were scored 
as positive if the change in $\mathrm{OD}_{550}$ was greater then $0 \cdot 300$. Strains grew best in TSB with the addition of $15 \%(\mathrm{w} / \mathrm{v})$ $\mathrm{NaCl}$, while growth was poor in TSB without added salt. Growth was observed in the $\mathrm{pH}$ range $6 \cdot 0-9 \cdot 0$, with optimal growth at $\mathrm{pH} 7 \cdot 0$. The standard incubation temperature was $28^{\circ} \mathrm{C}$. The growth range was tested on NA plates at different temperatures. Good growth was also observed at $20^{\circ} \mathrm{C}$; growth was weak at $15^{\circ} \mathrm{C}$. At $37^{\circ} \mathrm{C}$, only strain LMG 22062 was able to grow.

Purification of total genomic DNA was performed as described by Heyndrickx et al. (1996). Repetitive sequencebased PCR genomic fingerprinting was performed with the (GTG) 5 primer (Versalovic et al., 1994), applying the PCR conditions described by Rademaker \& de Bruijn (1997). Electrophoresis and pattern analysis were further performed as described by Heyrman et al. (2003). Sequence analysis was performed as described previously by Heyrman \& Swings (2001). Phylogenetic trees were constructed using BioNumerics software (Applied Maths) by applying the neighbour-joining and maximum-parsimony methods on a multiple alignment similarity matrix. The stability of relationships was assessed by using a bootstrap analysis of 1000 datasets (Fig. 1). The G+C content of DNA was determined by HPLC (Mesbah et al., 1989) using further specifications as given by Logan et al. (2000). The three strains showed nearly identical (GTG) 5 patterns, with internal Pearson correlation above $90 \%$ (data not shown). This high genotypic similarity was further confirmed by partial $16 \mathrm{~S}$ rRNA gene sequencing. The first $473 \mathrm{bp}$ of the gene were determined and the sequence obtained for LMG $22061^{\mathrm{T}}$ differed only by one base deletion in comparison with the identical sequences of LMG 22062 and LMG 22063. For LMG 22061 $1^{\mathrm{T}}$, an almost complete $16 \mathrm{~S}$ rRNA gene sequence (1493 bp) was determined. Sequence similarity calculations after a neighbour-joining analysis indicated that the closest relatives of strain LMG $22061^{\mathrm{T}}$ were Brevibacterium casei $(96.7 \%)$, Brevibacterium iodinum (96.7\%), Brevibacterium linens (96.6\%), Brevibacterium epidermidis (96.2\%) and Brevibacterium avium (96.2\%). Sequence similarities to the other recognized species of
Brevibacterium, excluding the species with an uncertain affiliation (see above), were in the range $93 \cdot 2-93 \cdot 5 \%$. The $16 \mathrm{~S}$ rRNA gene sequences of Brevibacterium stationis and Brevibacterium halotolerans, previously not available in the GenBank/EMBL/DDBJ databases, were also analysed and included in the phylogenetic analyses (Fig. 1). The sequence of Brevibacterium stationis showed $98 \cdot 8 \%$ similarity to those of the type strains of Corynebacterium ammoniagenes and Corynebacterium casei. This is in accordance with the statement of Jones \& Keddie (1986), namely that Brevibacterium stationis is a member of the genus Corynebacterium. The additional statement that Brevibacterium stationis and C. ammoniagenes may even belong to the same species cannot be confirmed on the basis of the 16S rRNA gene sequence data alone. Brevibacterium halotolerans showed the highest sequence similarity to Bacillus mojavensis and Bacillus subtilis (respective similarities of $99 \cdot 9$ and $99 \cdot 7 \%$ ). Attribution to the genus Bacillus would be in accordance with the unsaturated menaquinones with seven isoprene units being found in Brevibacterium halotolerans (Collins et al., 1981) yet not in other members of Brevibacterium. Brevibacterium frigoritolerans was not sequenced, but fatty acid analysis (performed as previously described by Heyrman et al., 1999) of the type strain LMG $21659^{\mathrm{T}}$ attributed the species to Bacillus megaterium (with percentage similarity to the TSBA4.0 database of $0 \cdot 600$ $0 \cdot 702$ ), thus also confirming its previously reported uncertain taxonomic position (Jones \& Keddie, 1986). The DNA $\mathrm{G}+\mathrm{C}$ content $(\mathrm{mol} \%)$ determined for strain LMG $22061^{\mathrm{T}}$ was $63.3 \%$, which is in accordance with the range of the other brevibacteria (see Table 1). Generally recommended and accepted criteria for delineating bacterial species state that strains showing $3 \%$ or more $16 \mathrm{~S}$ rRNA gene sequence dissimilarity are considered representatives of separate species (Stackebrandt \& Goebel, 1994; Stackebrandt et al., 2002). Since this was the case for the investigated isolates from the mural painting, they could be attributed to a separate genospecies without additional DNA-DNA relatedness experiments.

Analysis of the fatty acid contents of the cell wall was

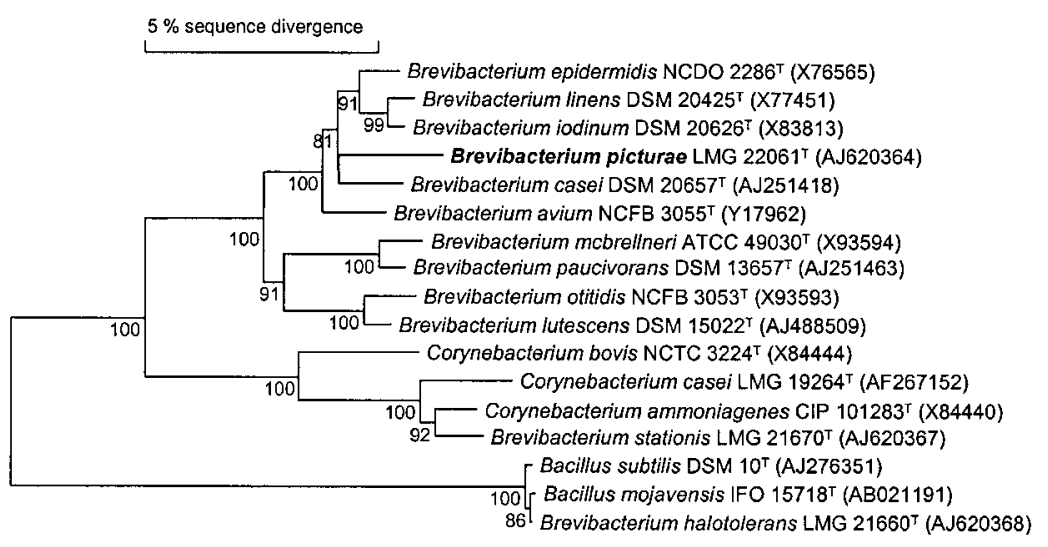

Fig. 1. Phylogenetic positions based on neighbour-joining of the 16S rRNA gene sequence of strain LMG $22061^{\top}$, representative of the isolates from the mural painting, among the species of Brevibacterium. For Brevibacterium species that fell outside the main cluster, the closest relatives, according to a FASTA search (Pearson \& Lipman, 1988), were included in the tree. Accession numbers are given in parentheses. Bootstrap values (expressed as percentages of 1000 replications) greater than $60 \%$ are shown at branch points. A phylogenetic tree based on the maximum-parsimony algorithm was in good accordance with this tree (data not shown). 
Table 1. Differentiating characteristics of $B$. picturae $\mathrm{sp}$. nov. and the other species phylogenetically attributed to Brevibacterium

Species: 1, Brevibacterium picturae sp. nov.; 2, Brevibacterium linens (Collins et al., 1980); 3, Brevibacterium iodinum (Collins et al., 1980); 4, Brevibacterium casei (Collins et al., 1983); 5, Brevibacterium epidermidis (Collins et al., 1983); 6, Brevibacterium avium (Pascual \& Collins, 1999); 7, Brevibacterium mcbrellneri (McBride et al., 1993); 8, Brevibacterium otitidis (Pascual et al., 1996); 9, Brevibacterium paucivorans (Wauters et al., 2001); 10, Brevibacterium lutescens (Wauters et al., 2003). +, Positive; W, weakly positive; - negative; V, variable; ND, not determined; ?, conflicting results between data in species description and table of differentiating characteristics.

\begin{tabular}{|c|c|c|c|c|c|c|c|c|c|c|}
\hline Characteristic & 1 & 2 & 3 & 4 & 5 & 6 & 7 & 8 & 9 & 10 \\
\hline \multicolumn{11}{|l|}{ Growth at: } \\
\hline $20^{\circ} \mathrm{C}$ & + & + & + & + & + & ND & - & $-\dagger$ & - & + \\
\hline Oxidase & - & $\mathrm{W}$ & + & - & - & + & - & ND & ND & $\mathrm{ND}$ \\
\hline Growth on $10 \% \mathrm{NaCl}$ & + & $+^{*}$ & $+^{*}$ & + & + & ND & - & $-\dagger$ & $-\dagger$ & + \\
\hline Pyrrolidonyl arylamidase & - & - & - & $\mathrm{V}$ & - & ND & - & $+\dagger$ & - & + \\
\hline Urease & + & $-*$ & $-*$ & - & - & - & - & - & - & - \\
\hline Lipase (C14) & - & ND & ND & $\mathrm{ND}$ & $\mathrm{ND}$ & - & ND & - & - & + \\
\hline Cystine arylamidase & - & ND & ND & ND & ND & + & ND & + & - & - \\
\hline Major menaquinones & MK-8 $\left(\mathrm{H}_{2}\right)$ & $\mathrm{MK}-8\left(\mathrm{H}_{2}\right)$ & $\mathrm{MK}-8\left(\mathrm{H}_{2}\right)$ & $\begin{array}{r}\text { MK-8 }\left(\mathrm{H}_{2}\right), \\
\operatorname{MK}-7\left(\mathrm{H}_{2}\right)\end{array}$ & $\mathrm{MK}-8\left(\mathrm{H}_{2}\right)$ & ND & $\mathrm{ND}$ & ND & ND & ND \\
\hline
\end{tabular}

${ }^{*}$ Data from Jones \& Keddie (1986).

$\dagger$ Data from Wauters et al. (2003).

performed as described previously (Heyrman et al., 1999), starting from cells grown on TSA for $48 \mathrm{~h}$. Purified cell-wall preparations were obtained by the method of Schleifer \& Kandler (1972). Menaquinones were extracted as described by Collins et al. (1977) and were analysed by HPLC (Groth et al., 1997). Polar lipids extracted by the method of Minnikin et al. (1979) were identified by two-dimensional TLC and spraying with specific reagents (Collins \& Jones, 1980). The absence of mycolic acids was demonstrated by using TLC (Minnikin et al., 1975). The fatty acid profile of the three strains (given in the species description) showed a predominance of the fatty acids anteiso- $\mathrm{C}_{15: 0}$ and anteiso$\mathrm{C}_{17: 0}$, which is in accordance with those of the other species of Brevibacterium (available as supplementary data in IJSEM Online). Funke \& Carlotti (1994) studied several Brevibacterium species by means of fatty acid analysis and found that anteiso- $\mathrm{C}_{15: 0}$ and anteiso- $\mathrm{C}_{17: 0}$ comprised more than $75 \%$ of the total fatty acid content for all strains studied. They concluded that this feature could be applied to differentiate members of Brevibacterium from other Gram-positive non-fermenters at the generic level. The species Brevibacterium mcbrellneri (McBride et al., 1993) and Brevibacterium otitidis (Wauters et al., 2003), and the Brevibacterium species of uncertain taxonomic position, do not correspond with this general observation. In a clustering based on the unweighted pair group method with arithmetic averages of Euclidian distances (not including Brevibacterium otitidis and Brevibacterium lutescens, data not shown), the isolates from mural paintings formed a tight cluster and grouped closest with the MIDI database reference of Brevibacterium iodinum ( $>99 \%$ similarity). Brevibacterium frigoritolerans, Brevibacterium halotolerans and Brevibacterium stationis showed profiles deviating from those of the other Brevibacterium species, which is in accordance with literature data (see above) and the additional 16S rRNA gene sequence analysis performed in this study. For strain LMG $22061^{\mathrm{T}}$, it was shown that the cell-wall peptidoglycan contains meso-diaminopimelic acid, type $\mathrm{A} 1 \gamma$ (direct cross-linkage), that the major menaquinone is $\mathrm{MK}-8\left(\mathrm{H}_{2}\right)$ and that mycolic acids are absent, all of which are in accordance with the genus description. Strain LMG $22061^{\mathrm{T}}$ contains diphosphatidylglycerol and phosphatidylglycerol, as do all other brevibacteria tested (Jones \& Keddie, 1986), plus phosphatidylinositol, one unknown phospholipid and one unknown glycolipid. The presence of phosphatidylinositol has been shown to vary with cultural conditions (Jones \& Keddie, 1986).

The results of the physiological characterization are given in the species description. Cell morphology and Gram staining were examined using phase-contrast and normal light microscopy, respectively. Catalase and oxidase determinations were performed according to the methods described by Smibert \& Krieg (1994). Anaerobic growth was tested in an anaerobic chamber on NA. API ZYM and API CORYNE strips (bioMérieux) were used according 
to the manufacturer's instructions. The isolates from the mural painting can be differentiated from all other Brevibacterium species by a positive urease reaction. Further phenotypic characteristics that can be used to differentiate between the isolates from the mural painting and the other Brevibacterium species are shown in Table 1.

\section{Description of Brevibacterium picturae sp. nov.}

Brevibacterium picturae (pic.tu'rae. L. gen. n. picturae pertaining, or belonging, to a painting).

Cells are Gram-positive, non-motile and non-sporeforming. On NA, no clear rod-coccus cycle is observed: after 6 and 16 h growth, cells are coccoid and occur singly $(0.8$ and $1.0 \mu \mathrm{m}$ in diameter, respectively); after $24 \mathrm{~h}$, cells are coccoid to oval; after $72 \mathrm{~h}$ growth, cells are oval or short rods occurring singly or in pairs $(1 \cdot 0 \times 1 \cdot 5-4 \mu \mathrm{m})$. Colonies on NA are white, low-convex, slightly transparent to opaque and circular with entire margins. Optimal growth occurs between 20 and $30^{\circ} \mathrm{C}$. Growth at $15^{\circ} \mathrm{C}$ is weak and no growth is observed at $10{ }^{\circ} \mathrm{C}$. At $37^{\circ} \mathrm{C}$, growth is variable (positive only for LMG 22062). The $\mathrm{pH}$ range for growth is 6-9, with an optimum at $\mathrm{pH}$ 7. Good growth occurs at $\mathrm{NaCl}$ concentrations of 5, 10 and $15 \%(\mathrm{w} / \mathrm{v})$. No growth observed in an anaerobic chamber. Catalase-positive and oxidase-negative. In the API CORYNE system, pyrazinamidase, alkaline phosphatase, urease and gelatin hydrolysis are positive. Pyrrolidonyl arylamidase, $\beta$-glucuronidase, $\alpha$-glucosidase, $N$-acetyl- $\beta$-glucosaminidase, aesculin $(\beta$ glucosidase) and fermentation of ribose, xylose, mannitol and glycogen are negative. The following reactions give variable results: nitrate reduction, $\beta$-galactosidase and acid production from glucose, maltose, lactose and sucrose. Of the additional tests in the API ZYM system, esterase (C4), esterase lipase (C8) and naphthol-AS-BI-phosphohydrolase are weakly positive. Leucine arylamidase and acid phosphatase are variable (if positive, weak). Lipase (C14), valine arylamidase, cystine arylamidase, trypsin, chymotrypsin, $\alpha$-galactosidase, $\beta$-glucosidase, $\alpha$-mannosidase and $\alpha$ fucosidase are negative. The type strain is positive for glucose fermentation, weakly positive for acid phosphatase and negative for nitrate reduction, $\beta$-galactosidase, leucine arylamidase and acid production from maltose, lactose and sucrose. The major fatty acids are anteiso- $\mathrm{C}_{15: 0}$ and anteiso- $\mathrm{C}_{17: 0}$ (present at about 60 and $27 \%$, respectively). Other fatty acids present at levels of at least $1 \%$ are iso$\mathrm{C}_{15: 0}( \pm 5 \%)$, iso- $\mathrm{C}_{16: 0}( \pm 3 \%)$, anteiso- $\mathrm{C}_{17: 1} \mathrm{~A}( \pm 3 \%)$ and iso- $\mathrm{C}_{17: 0}( \pm 1 \%)$. The type strain shows the following chemotaxonomic characteristics: the diamino acid of the peptidoglycan is meso-diaminopimelic acid; the major menaquinone is MK-8 $\left(\mathrm{H}_{2}\right)$; mycolic acids are absent; and the polar lipids are phosphatidylglycerol, diphosphatidylglycerol, phosphatidylinositol, an unknown phospholipid and an unknown glycolipid.

Isolated from a mural painting discoloured by microbial growth. The $\mathrm{G}+\mathrm{C}$ content is $63 \cdot 3 \mathrm{~mol} \%$ for the type strain, strain LMG $22061^{\mathrm{T}}\left(=\right.$ DSM $\left.16132^{\mathrm{T}}\right)$.

\section{Acknowledgements}

The authors acknowledge the financial support of the European Commission (grant ENV4-CT98-0705). J. S. and P.D. V. are grateful to the Fund for Scientific Research, Flanders, for research and personnel grants. J. H. acknowledges Ghent University for his BOF grant.

\section{References}

Breed, R. S. (1953). The families developed from Bacteriaceae Cohn with a description of the family Brevibacteriaceae. Riass Commun VI Congr Int Microbiol Roma 1, 10-15.

Collins, M. D. (1992). The genus Brevibacterium. In The Prokaryotes, 2nd edn, vol. 2, pp. 1351-1354. Edited by A. Balows, H. G. Trüper, M. Dworkin, W. Harder \& K.-H. Schleifer. New York: Springer.

Collins, M. D. \& Jones, D. (1980). Lipids in the classification and identification of coryneform bacteria containing peptidoglycans based on 2,4-diaminobutyric acid. J Appl Bacteriol 48, 459-470.

Collins, M. D., Pirouz, T., Goodfellow, M. \& Minnikin, D. E. (1977). Distribution of menaquinones in actinomycetes and corynebacteria. J Gen Microbiol 100, 221-230.

Collins, M. D., Jones, D., Keddie, R. M. \& Sneath, P. H. A. (1980). Reclassification of Chromobacterium iodinum (Davis) in a redefined genus Brevibacterium (Breed) as Brevibacterium iodinum nom. rev.; comb. nov. J Gen Microbiol 120, 1-10.

Collins, M. D., Ross, H. N. M., Tindall, B. J. \& Grant, W. D. (1981). Distribution of isoprenoid quinones in halophilic bacteria. J Appl Bacteriol 50, 559-564.

Collins, M. D., Farrow, J. A. E., Goodfellow, M. \& Minnikin, D. E. (1983). Brevibacterium casei sp. nov. and Brevibacterium epidermidis sp. nov. Syst Appl Microbiol 4, 388-395.

Euzeby, J. P. \& Tindall, B. J. (2004). Status of strains that contravene rules 27(3) and 30 of the Bacteriological Code. Request for an opinion. Int J Syst Evol Microbiol 54, 293-301.

Funke, G. \& Carlotti, A. (1994). Differentiation of Brevibacterium spp. encountered in clinical specimens. J Clin Microbiol 32, 1729-1732.

Gelsomino, R., Vancanneyt, M. \& Swings, J. (2004). Reclassification of Brevibacterium liquefaciens Okabayashi and Masuo 1960 as Arthrobacter nicotianae Giovannozzi-Sermanni 1959. Int J Syst Evol Microbiol 54, 615-616.

Groth, I., Schumann, P., Rainey, F. A., Martin, K., Schuetze, B. \& Augsten, K. (1997). Demetria terragena gen. nov., sp. nov., a new genus of actinomycetes isolated from compost soil. Int J Syst Bacteriol 47, 1129-1133.

Heyndrickx, M., Vauterin, L., Vandamme, P., Kersters, K. \& De Vos, P. (1996). Applicability of combined amplified ribosomal DNA restriction analysis (ARDRA) patterns in bacterial phylogeny and taxonomy. J Microbiol Methods 26, 247-259.

Heyrman, J. \& Swings, J. (2001). 16S rDNA sequence analysis of bacterial isolates from biodeteriorated mural paintings in the Servilia tomb (necropolis of Carmona, Seville, Spain). Syst Appl Microbiol 24, 417-422.

Heyrman, J., Mergaert, J., Denys, R. \& Swings, J. (1999). The use of fatty acid methyl ester analysis (FAME) for the identification of heterotrophic bacteria present on three mural paintings showing severe damage by microorganisms. FEMS Microbiol Lett 181, 55-62.

Heyrman, J., Logan, N. A., Busse, H.-J., Balcaen, A., Lebbe, L., Rodriguez-Diaz, M., Swings, J. \& De Vos, P. (2003). Virgibacillus carmonensis sp. nov., Virgibacillus necropolis sp. nov. and Virgibacillus picturae sp. nov., three novel species isolated from deteriorated mural paintings, transfer of the species of the genus Salibacillus to Virgibacillus, as Virgibacillus marismortui comb. nov. 
and Virgibacillus salexigens comb. nov., and emended description of the genus Virgibacillus. Int J Syst Evol Microbiol 53, 501-511.

Jones, D. \& Keddie, R. M. (1986). Genus Brevibacterium. In Bergey's Manual of Systematic Bacteriology, vol. 2, pp. 1301-1313. Edited by P. H. Sneath, N. Mair, M. E. Sharpe \& J. G. Holt, Baltimore: Williams \& Wilkins.

Logan, N. A., Lebbe, L., Hoste, B. \& 7 other authors (2000). Aerobic endospore-forming bacteria from geothermal environments in northern Victoria Land, Antarctica, and Candlemas Island, South Sandwich archipelago, with the proposal of Bacillus fumarioli sp. nov. Int J Syst Evol Microbiol 50, 1741-1753.

McBride, M. E., Ellner, K. M., Black, H. S., Clarridge, J. E. \& Wolf, J. E. (1993). A new Brevibacterium sp. isolated from infected genital hair of patients with white piedra. J Med Microbiol 39, 255-261.

Mesbah, M., Premachandran, U. \& Whitman, W. B. (1989). Precise measurement of the $\mathrm{G}+\mathrm{C}$ content of deoxyribonucleic acid by high-performance liquid chromatography. Int J Syst Bacteriol 39, 159-167.

Minnikin, D. E., Alshamaony, L. \& Goodfellow, M. (1975). Differentiation of Mycobacterium, Nocardia, and related taxa by thin-layer chromatographic analysis of whole-organism methanolysates. J Gen Microbiol 88, 200-204.

Minnikin, D. E., Collins, M. D. \& Goodfellow, M. (1979). Fatty acid and polar lipid composition in the classification of Cellulomonas, Oerskovia and related taxa. J Appl Bacteriol 47, 87-95.

Pascual, C. \& Collins, M. D. (1999). Brevibacterium avium sp. nov., isolated from poultry. Int J Syst Bacteriol 49, 1527-1530.

Pascual, C., Collins, M. D., Funke, G. \& Pitcher, D. G. (1996). Phenotypic and genotypic characterization of two Brevibacterium strains from the human ear: description of Brevibacterium otitidis sp. nov. Med Microbiol Lett 5, 113-123.

Pearson, W. R. \& Lipman, D. J. (1988). Improved tools for biological sequence comparison. Proc Natl Acad Sci U S A 85, 2444-2448.

Rademaker, J. L. W. \& de Bruijn, F. J. (1997). Characterization and classification of microbes by rep-PCR genomic fingerprinting and computer assisted pattern analysis. In DNA Markers: Protocols, Applications and Overviews, pp. 151-171. Edited by G. GaetanoAnollés \& P. M. Gresshoff. New York: Wiley.

Schleifer, K. H. \& Kandler, O. (1972). Peptidoglycan types of bacterial cell walls and their taxonomic implications. Bacteriol Rev 36, 407-477.

Smibert, R. M. \& Krieg, N. R. (1994). Phenotypic characterization. In Methods for General and Molecular Bacteriology, pp. 607-654. Edited by P. Gerhardt, R. G. E. Murray, W. A. Wood \& N. R. Krieg. Washington, DC: American Society for Microbiology.

Stackebrandt, E. \& Goebel, B. M. (1994). Taxonomic note: a place for DNA-DNA reassociation and 16S rRNA sequence analysis in the present species definition in bacteriology. Int J Syst Bacteriol 44, 846-849.

Stackebrandt, E., Fowler, V. J., Fiedler, F. \& Seiler, H. (1983). Taxonomic studies on Arthrobacter nicotianae and related taxa: description of Arthrobacter uratoxydans sp. nov. and Arthrobacter sulfureus sp. nov. and reclassification of Brevibacterium protophormiae as Arthrobacter protophormiae comb. nov. Syst Appl Microbiol 4, 470-486.

Stackebrandt, E., Frederiksen, W., Garrity, G. M. \& 10 other authors (2002). International Committee on Systematic Bacteriology. Report of the ad hoc committee for the re-evaluation of the species definition in bacteriology. Int J Syst Evol Microbiol 52, 1043-1047.

Versalovic, J., Schneider, M., de Bruijn, F. J. \& Lupksi, J. R. (1994). Genomic fingerprinting of bacteria using repetitive sequence-based polymerase chain reaction. Methods Mol Cell Biol 5, 25-40.

Wauters, G., Charlier, J., Janssens, M. \& Delmée, M. (2001). Brevibacterium paucivorans sp. nov., from human clinical specimens. Int J Syst Evol Microbiol 51, 1703-1707.

Wauters, G., Avesani, V., Laffineur, K., Charlier, J., Janssens, M., Van Bosterhaut, B. \& Delmée, M. (2003). Brevibacterium lutescens sp. nov., from human and environmental samples. Int J Syst Evol Microbiol 53, 1321-1325. 